\title{
Pay or not to Pay Dividends: Company Policy and Investor Expectations
}

\section{Kanwal Iqbal Khan", Muhammad Mudassar Ghafoor*, Muhammad Sheeraz $^{* * *}$ and Shahid Mahmood ${ }^{* * * *}$}

\begin{abstract}
This paper attempts to understand the linkage of dividend decisions and investors' perceptions within the context of the Pakistani corporate sector. It is intended to proffer new evidence for designing dividend policies that satisfies investors' perceptions. Data are collected from individual investors by using questionnaires to obtain opinions about essential factors, patterns, processes and preferences for cash dividends. Results indicate that stability in the rate of dividend, compatibility with the inflation rate and continuity of dividend payment are the topranking factors for investors. Stock dividends are preferred by Pakistani investors if their company is not paying cash dividends, and share buy-back decisions are taken negatively. The theoretical explanation for preferring dividends indicates that Pakistani investors support dividend signaling theory, agency cost, clientele effect, asymmetric information effect, tax effect and rational expectation models. That is why it exhibits a positive relation between dividends and investors' perception. The contributions and recommendations for further studies are also addressed.
\end{abstract}

Keywords: Dividend Policies, investors perception, dividend theories

JEL Classification: G11, G35, G41.

\section{Introduction}

Dividend policy remains a widely-investigated issue in the field of corporate finance due to its linkage with financing and investment decisions and its ultimate impact on organizational value. It can prove an unsolvable puzzle for corporate managers. Despite its importance, two

\footnotetext{
* Institute of Business \& Management, University of Engineering and Technology, Lahore, Pakistan. Email: drkanwaliqbalkhan@gmail.com

** Director and Assistant Professor, University of the Punjab Jehlum Campus, Jehlum, Pakistan. Email: smudasar@pugc.edu.pk

*** Assistant Professor, Lahore Business School, The University of Lahore, Lahore, Pakistan.

***** Assistant Professor, Department of Commerce, The Islamia University of Bahawalpur, Bahawalpur, Pakistan.
} 


\section{Shahid Mahmood}

contending opinions have emerged in the literature about dividend policy. One stream of researchers has viewed it as relevant for designing corporate financial strategies, whereas the other stream has proclaimed it as irrelevant. Ross, Westerfield, and Jaffe (2013) have identified it as a twohanded lawyer problem: from one aspect, financial economists regard it as pertinent, whereas from another point of view, financial economists consider it unrelated. Dividend policy has become an unresolved issue in the field of finance (Ehrhardt \&Brigham, 2016).

Dividend policy is equally important for managers and investors. Investors consider it a consistent source of income and a signaling mechanism of performance. Management pays close attention in designing their dividend policies as it affects stock value as well as investment decisions (Yao, Baker, \& Powell, 2012). Management success is also measured by its ability to maximize shareholder value (Naser, Nuseibeh, \& Rashed, 2013), which can be achieved through the complete knowledge of the dividend policy mechanism.

Previous studies have been based either on the opinion of financial officers (Brav, Graham, Harvey, \& Michaely, 2005), executives (Yao et al., 2012) or managers (Baker \& Jabbouri, 2016; Butler, Grullon, \& Weston, 2005; Naser et al., 2013) in formulating and designing their dividend policies. However, limited studies have been conducted to explore the perceptions of investors directly about dividend decisions (Dong, Robinson, \& Veld, 2005; Lee, Rosenthal, Veld, \& Veld- Merkoulova, 2015; Maditinos, Sevic, Theriou, \& Tsinani, 2007).

The study is an attempt to determine the behavior of individual Pakistani investors in the event of a change in dividend policy, primarily when the dividend is paid and when it is not. This study applies dividend theories to enrich the literature in the field of finance and demonstrates that dividend policies, stock prices, and investor's perception are closely associated. Dividend theories are empirically tested, and its effect on individual investor's behavior is observed. This paper presents new insight into dividend policy by highlighting the investors' perspective within the context of the Pakistani corporate sector.

The current study has the following objectives:

- Identify and rank the essential factors that individual investors perceive as affecting their dividend policies. 
- Express the opinions of investors about dividend processes and patterns, stock dividends, share repurchase and firm value.

- Provide theoretical and empirical support for individual investors regarding dividend preferences.

\section{Literature Review}

Previous studies provide evidence of a relationship between dividend policy and investor perception, and different theories and factors have been advanced in the literature to explain this relationship. Dong et al. (2005) have conducted a survey of individual investors, collecting their opinions about dividend policies. Results of their study have proclaimed that cash dividend is preferred over stock dividend, and, in case the company is incapable of cash payment, a stock dividend would be acceptable. Similarly, Maditinos et al. (2007) have investigated the dividend preferences of investors and have also confirmed similar cash dividend preference in Greek investors. Furthermore, the study found that wealthy investors preferred stock dividend over cash dividend in order to enhance their investment.

Korkeamaki, Liljeblom and Pasternack (2010) have stated that changes in dividend tax rate has a necessary implication in designing dividend policy. Companies adjust their dividend payout accordingly, consistent with shareholder clientele, adjusting to the new tax system. Brennan and Thakor (1990) have explained the importance of dividend policy for the shareholders, indicating that in the presence of taxes, the majority of shareholders prefer dividends for small distribution, capital gains for large distribution and share repurchases for the largest distributions. Mathur, Singh, Nejadmalayeri and Jiraporn (2013) have stated that bond investors take large dividend payments negatively.

Baker and Wurgler (2002) have surveyed dividend-paying firms to discover the opinions of practitioners regarding the relationship between dividend policy and firm value. Their study has found that managers prefer to carry on stable dividend policies which will ultimately impact stock prices in the market. Similarly, it is empirically evident that dividend policy and investors' perceptions are closely related to each other. Jong Ronald and Chris (2003) have examined the relationship between dividend policies and repurchase decisions in Canadian firms and have concluded that companies decide cash payment based on cash flow. 


\section{Shahid Mahmood}

Another study observed the opinions of CFO and Treasurers of various firms regarding dividend policy and investor's behavior (Brav et al., 2005). The study concluded that financial executives confirmed the investors' high priority toward dividends (while ignoring tax disadvantage). Likewise, a study by Anand (2004) surveyed financial executives (CFO) from 500 Indian companies and found that dividend policy has importance for shareholders as well as financial experts and decision makers. This assertion is consistent with our view that dividend policies are preferred to be consistent to perform in accordance with shareholder expectations. Each of these empirical findings provide justification for the present study, which aims to express the opinion of individual investors about dividend decisions based on theories.

\section{Theories for Dividend Policy}

The major theories of dividend policy justifying cash dividend preferences are illustrated below:

\subsection{Bird-in-Hand Theory}

According to this theory, the dividend policy of a company has a strong effect on stock market prices. Shareholders of a company expect either dividends or capital gains as compensation for their investment. Risk-averse shareholders, however, tend to desire current and stable income (such as cash dividends) over uncertain income (such as capital gains) (Gordon, 1959; Khan, 2012; Lintner, 1956).

\section{2. $\quad$ Signaling Theory}

This theory postulates that dividends act as a signal to convey growth of the company in the eyes of shareholders. Company managers possess insights into information and therefore are expected to disseminate key information to investors or shareholders of the company. These signals can be positive (consistency or increase in dividend) or negative (lack of dividend or decrease in dividend) which would ultimately decrease or increase share price (Asquith \& Mullins, 1986; Mathur et al., 2013; Travlos, Trigeorgis, \& Vafeas, 2001).

\subsection{Agency Cost Theory}

The term agency can be understood as a relationship of shareholders and management, whereas agency cost is the difference 
between the interest of shareholders and decision makers (management) (Jensen \& Meckling, 1976). This study also advocates that within an organization, equity ownership of decision makers has a significant impact on the dividend policy of the company. Agency cost can be divided into two parts: monitoring (Easterbrook, 1984) and avoiding risks (Mathur et al., 2013).

\subsection{Clientele Effect}

This theory explains that investors keenly observe dividend policies of various firms and maintain their stock holdings concerning the information gained. Consequently, investors tend to maintain or increase the stock of companies that convey consistent dividend policy in accordance with their perception. In the case of a change in perception of dividend policy, the investor will promptly divest the company's stock and invest in any other company's shares. However, investor attitude is based on preference toward dividend gains, rather than capital gains, due to a lower level of risk associated with it. Thus, it can be concluded that reliable and constant dividend policy has a greater impact on investor behavior, rather than the policy itself (Anand, 2004; Korkeamaki et al., 2010).

\subsection{Asymmetric Information}

In a competitive market, there should be a similar level of information accessible to all stakeholders of the company (such as decision makers, shareholders and credit providers). However, in real-life situations, this becomes impossible, and one member of the group may have more in-depth information regarding investment opportunities in the future and upcoming projects. This situation creates information asymmetry in the market, and one group may dominate due to information accessibility over others (Miller \& Rock, 1985). In general, this dominating group with in-depth information may include directors and managers of the company with key decision powers. The managers and directors having in-depth information will ultimately lead to a change in prices of the company's stock in the market (Khan et al., 2011).

\subsection{Tax Preference Theory}

This theory postulates that the imposition of tax on dividend income can impact the net return of investors and therefore they tend to focus less on dividend policy in comparison to capital gains (which bear less tax). It can be argued that investors prefer capital gains over dividend due to a 
higher level of control on capital gains (Jong et al., 2003). Baker and Wurgler (2002) and Maditinos et al. (2007) have provided some support to the theory, whereas Brav et al. (2005) have found that CFO's of a company tend to deprioritize the taxes in designing their dividend policy.

\subsection{Residual Theory}

This theory considers dividend as residual income and recommends managers pay dividends if the company lacks inside growth or investment opportunities. This theory prioritizes the internal investment needs of the company, followed by disbursement of the remaining amount as a dividend to shareholders. Therefore, the company should strongly emphasize internal investment rather than disbursement of dividends to shareholders (Baker, Powell, \& Veit, 2002; Korkeamaki et al., 2010).

\subsection{Rational Expectations Model}

This theory considers dividend policy that does not disturb the stock market prices as extraneous. The anticipation of investors regarding dividend policy is the major factor that can influence stock market prices of the organization (Clark-Murphy \& Soutar, 2004). Stockholders have certain beliefs about the dividend policy, and if the organization successfully meets their expectations, and declares dividends per their perception, then prices will go up or stay unaltered (Khan et al., 2011). Otherwise, the company will face price distress and its earnings will go down more than anticipated (Akbar \& Baig, 2010).

\section{Research Methodology}

\subsection{Research Design}

Our study was cross-sectional, analytical and was completed with minimal interference from researchers in a non-contrived setting. Individual investors who own the stocks of listed companies are the unit of analysis. Purposive sampling technique was adopted for sample selection along with the following criteria: a) investors own the stocks of listed companies, b) investors must have sufficient knowledge of investment terminology and dividend theories, and c) investors must be aware of current stock market conditions, rules and regulations. Keeping in mind the research design, data were collected from finance students who are also the regular investors specially obtaining dividend-paying stocks. Previous studies have shown that students are the suitable sample for this 
type of study due to their knowledge and experience in the relevant field (Beal \& Delpachitra, 2003; Chen \& Volpe, 1998). The selected students were also aware of stock market terminology and dividend theories. Data collection involved distribution of 200 questionnaires; a total of 149 were returned back to the researchers. However, the screening process found 131 completed usable questionnaires, with the remainder consisting of incomplete, flawed and non-useable questionnaires. Data collection process yielded an overall response rate of 66 per cent, which is considered good among researchers in social sciences (Babbie, 2015).

The questionnaire was developed after viewing the survey instruments of Baker and Jabbouri (2016) and Maditinos et al. (2007). The questionnaire consisted of three sections. Section 1 included six questions describing respondents' characteristics and industries of investment. Section 2 included 20 statements explaining the level of importance, from none (0) to high (3), for important factors affecting dividend policy decisions and dividend patterns. Finally, Section 3 included 38 statements measured on a 5-point Likert scale from strongly disagree (1) to strongly agree (5) to explain the investors' level of agreement regarding dividend issues and their preferences for cash dividends.

\section{Results}

\subsection{Respondents Characteristics}

Table 1 shows that 15 per cent of the investors who participated in this study are below 25 years of age, out of which 12.9 per cent are graduates, and 17 per cent have a master's degree. 49 per cent fall into category two for age (i.e. 26-30 years), out of which 48 per cent are graduates, and 49 per cent are master's degree holders. 36 percent are in the 3 rd category for age (i.e. above 30 years), out of which 39 per cent have completed their graduation, and 33 per cent have finished their master's degree. The participation of male (76 per cent) investors was more than female ( 24 per cent) in this research. 73 per cent of the males are graduates, and 80 per cent are master's degree holders, while among females, this percentage is lower, i.e. 27 per cent for graduate and 20 per cent for master's degree. 

Shahid Mahmood

\section{Table 1: Respondents Characteristics}

\begin{tabular}{|c|c|c|c|c|c|c|c|}
\hline \multirow{3}{*}{ Variables } & \multirow{3}{*}{ Category } & \multicolumn{4}{|c|}{ Qualification } & \multirow{2}{*}{\multicolumn{2}{|c|}{ Total }} \\
\hline & & \multicolumn{2}{|c|}{ Graduation } & \multicolumn{2}{|c|}{ Masters or Equivalent } & & \\
\hline & & Freq. & $\%$ & Freq. & $\%$ & Freq. & $\%$ \\
\hline \multirow{3}{*}{ Age } & Below 25 & 8 & 12.9 & 12 & 17.4 & 20 & 15.3 \\
\hline & $26-30$ & 30 & 48.4 & 34 & 49.3 & 64 & 48.9 \\
\hline & Above 30 & 24 & 38.7 & 23 & 33.3 & 47 & 35.9 \\
\hline \multirow{2}{*}{ Gender } & Male & 45 & 72.6 & 55 & 79.7 & 100 & 76.3 \\
\hline & Female & 17 & 27.4 & 14 & 20.3 & 31 & 23.7 \\
\hline Total & & 62 & 100 & 69 & 100 & 131 & 100 \\
\hline
\end{tabular}

\subsection{Industries of Investment}

The questionnaire included a question which inquired about the industries of respective investment in the stock market and investors were able to specify an industry of their choice, whether it was mentioned as an option or not. The open choice for investors to mention their own investment industries yielded three more industries to be included in the analysis: information, communication, and transport industries. These three industries are grouped combinedly. Table 2 demonstrates that 50 per cent of the investors either belong to mineral, fuel, and energy or cement and other manufacturing companies and earn less than Rs. 35,000. 46 per cent of the investors earn an income of Rs. 35,000 or more and belong to either mineral, fuel and energy or chemicals, fertilizer, and pharmaceutical industries.

Table 2: Respondents Industries of Investment

\begin{tabular}{|c|c|c|c|c|c|c|c|}
\hline \multirow{3}{*}{ Variables } & \multirow{3}{*}{ Category } & \multicolumn{4}{|c|}{ Monthly Income } & \multirow{2}{*}{\multicolumn{2}{|c|}{ Total }} \\
\hline & & \multicolumn{2}{|c|}{$\begin{array}{l}\text { Less than } \\
\text { Rs. } 35,000\end{array}$} & \multicolumn{2}{|c|}{$\begin{array}{c}\text { Rs. } 35,000 \\
\text { or more }\end{array}$} & & \\
\hline & & Freq. & $\%$ & Freq. & $\%$ & Freq. & $\%$ \\
\hline \multirow{6}{*}{$\begin{array}{l}\text { Major } \\
\text { Industry }\end{array}$} & Mineral, Fuel and Energy & 11 & 25.0 & 23 & 26.4 & 34 & 26.0 \\
\hline & $\begin{array}{l}\text { Chemicals, Fertilizer and } \\
\text { Pharmaceutical }\end{array}$ & 6 & 13.6 & 17 & 19.5 & 23 & 17.6 \\
\hline & Financial Institutions & 10 & 22.7 & 16 & 18.4 & 26 & 19.8 \\
\hline & $\begin{array}{l}\text { Cement and other } \\
\text { manufacturing }\end{array}$ & 11 & 25.0 & 16 & 18.4 & 27 & 20.6 \\
\hline & $\begin{array}{l}\text { Food and Personal Use } \\
\text { Information, }\end{array}$ & 3 & 6.8 & 7 & 8.0 & 10 & 7.6 \\
\hline & $\begin{array}{l}\text { Communication and } \\
\text { Transport }\end{array}$ & 3 & 6.8 & 8 & 9.2 & 11 & 8.4 \\
\hline Total & & 44 & 100 & 87 & 100 & 131 & 100 \\
\hline
\end{tabular}




\subsection{Factors Influencing Dividend Policy}

The first objective of our study was to identify the relevant factors that Pakistani investors consider necessary for their companies' dividend policies, and then rank them according to their importance. Table 3 includes 14 potential factors extracted from H. K. Baker and Kapoor (2015) with the addition of some other possible determinants of dividend policy, per the expectation of Pakistani investors. Respondents were requested to reveal essential predictors that can influence their priority dividend choices. They have presented a list of 14 factors with a given option to enter any relevant predictor, but they included no further factor.

Table 3: Factors Influencing Dividend Policy

\begin{tabular}{|c|c|c|c|c|c|c|c|c|}
\hline \multirow{3}{*}{ SR \# } & \multirow{3}{*}{ Factor } & \multicolumn{4}{|c|}{ Level of Importance (\%) } & \multirow{3}{*}{ Mean } & \multirow{3}{*}{ Std. } & \multirow{3}{*}{ t-value } \\
\hline & & None & Low & Mod & High & & & \\
\hline & & 0 & 1 & 2 & 3 & & & \\
\hline$\overline{\text { F5 }}$ & Stability in Rate of dividend & 0.8 & 15.3 & 9.2 & 74.8 & 2.580 & 0.774 & $38.147^{* *}$ \\
\hline F13 & $\begin{array}{l}\text { Compatible with Inflation } \\
\text { Rate }\end{array}$ & 0.0 & 1.5 & 28.2 & 70.2 & 2.687 & 0.497 & $61.825^{* *}$ \\
\hline F1 & $\begin{array}{l}\text { Continuity of dividend } \\
\text { Payment }\end{array}$ & 7.6 & 14.5 & 22.1 & 55.7 & 2.260 & 0.973 & $26.568^{* *}$ \\
\hline $\mathrm{F} 2$ & Pattern of past dividends & 0.0 & 18.3 & 26.7 & 55.0 & 2.366 & 0.777 & $34.874^{* *}$ \\
\hline F10 & $\begin{array}{l}\text { Projections about future } \\
\text { state of the economy }\end{array}$ & 3.8 & 27.5 & 29.0 & 39.7 & 2.046 & 0.910 & $25.722^{* *}$ \\
\hline F8 & Stability of dividend Amount & 1.5 & 13.7 & 46.6 & 38.2 & 2.214 & 0.734 & $34.525^{* *}$ \\
\hline F9 & Stability of earnings & 0.0 & 32.1 & 32.8 & 35.1 & 2.031 & 0.822 & $28.267^{* *}$ \\
\hline F7 & $\begin{array}{l}\text { Current degree of financial } \\
\text { leverage }\end{array}$ & 0.8 & 19.1 & 46.6 & 33.6 & 2.130 & 0.738 & $33.033^{* *}$ \\
\hline F6 & $\begin{array}{l}\text { Expected rate of return on } \\
\text { firm's assets }\end{array}$ & 10.7 & 16.0 & 43.5 & 29.8 & 1.924 & 0.942 & $23.385^{* *}$ \\
\hline F11 & $\begin{array}{l}\text { Level of expected future } \\
\text { earnings }\end{array}$ & 6.1 & 29.0 & 37.4 & 27.5 & 1.863 & 0.892 & $23.889^{* *}$ \\
\hline F12 & Contractual constraints & 4.6 & 19.1 & 51.9 & 24.4 & 1.962 & 0.788 & $28.480^{* *}$ \\
\hline $\mathrm{F} 4$ & Future investment projects & 3.8 & 26.0 & 48.1 & 22.1 & 1.885 & 0.791 & $27.292^{* *}$ \\
\hline F3 & Level of current earnings & 10.7 & 24.4 & 50.4 & 14.5 & 1.687 & 0.851 & $22.687^{* *}$ \\
\hline F14 & Desire for cash funds & 2.3 & 14.5 & 73.3 & 9.9 & 1.908 & 0.574 & $38.023^{* *}$ \\
\hline
\end{tabular}

${ }^{*} \mathrm{p}<0.05,{ }^{* *} \mathrm{p}<0.01$

Table 3 also shows their level of importance with mean, standard deviation values and corresponding t-statistic, which contains the null hypothesis (H0), as the mean response equals to 0 (no importance). We were primarily concerned with the highest-ranking score factors for establishing investors' perception about dividend policy. The four topranking factors were stability in the rate of dividend (74.8 per cent), 


\section{Shahid Mahmood}

compatible with inflation rate (70.2 per cent), continuity of dividend payment (55.7 per cent) and pattern of past dividends ( 55 per cent). All four of these factors exclusively represent investors' demand for dividends in real-income terms.

\subsection{Dividend Policy Issues}

Table 4 explains the investor's opinion related to different dividend policy issues, such as dividend patterns, process, stock dividends, share buy-back decisions, firm value and accounting manipulation. Panel A presents the importance of dividend patterns and then ranks them from the highest to the lowest values. Respondents were provided six dividend policy patterns and were asked to rank them according to the best description of their company's dividend policy. The responses indicated that 66 per cent of shareholders consider their company to follow fixed dividend (in percentage) of EPS policy, 55 per cent of stockholders believe that their companies adopt either regular dividend per share plus special dividend policy or dividend percentage of net income plus growth factor policy. However, 40 per cent of shareholders have the view that their companies do not have any pattern for dividend payments.

Table 4(a): Dividend Patterns

\begin{tabular}{|c|c|c|c|c|c|c|c|c|}
\hline \multirow{3}{*}{ SR \# } & \multirow{3}{*}{ Factor } & \multicolumn{4}{|c|}{ Level of Importance (\%) } & \multirow{3}{*}{ Mean } & \multirow{3}{*}{ Std. } & \multirow{3}{*}{ t-value } \\
\hline & & None & Low & Mod & High & & & \\
\hline & & 0 & 1 & 2 & 3 & & & \\
\hline \multicolumn{9}{|c|}{ Panel A. Dividend Patterns } \\
\hline F16 & $\begin{array}{l}\text { Fixed dividend (in } \\
\text { percentage) of EPS }\end{array}$ & 0 & 15.3 & 18.3 & 66.4 & 2.511 & 0.748 & $38.430^{* *}$ \\
\hline F18 & $\begin{array}{l}\text { Dividend \%age of Net } \\
\text { Income + growth factor }\end{array}$ & 3.8 & 18.3 & 22.9 & 55.0 & 2.290 & 0.899 & $29.168^{* *}$ \\
\hline F19 & $\begin{array}{l}\text { Constant dividend per share } \\
\text { plus special dividend }\end{array}$ & 3.1 & 21.4 & 20.6 & 55.0 & 2.275 & 0.903 & $28.819^{* *}$ \\
\hline F15 & $\begin{array}{l}\text { Fixed dividend in Rupees } \\
\text { Minor changes in the }\end{array}$ & 0 & 12.2 & 33.6 & 54.2 & 2.420 & 0.701 & $39.502^{* *}$ \\
\hline F17 & $\begin{array}{l}\text { dividend per share in terms } \\
\text { of Rupees or percentage }\end{array}$ & 0 & 9.9 & 38.2 & 51.9 & 2.420 & 0.667 & $41.498^{* *}$ \\
\hline F20 & $\begin{array}{l}\text { No pattern of Payment for } \\
\text { dividends }\end{array}$ & 15.3 & 22.9 & 21.4 & 40.5 & 1.870 & 1.112 & 19.247 \\
\hline
\end{tabular}

${ }^{*} \mathrm{p}<0.05,{ }^{* *} \mathrm{p}<0.01$

From Panel B to Panel F, 16 statements are included that explain investors' level of agreement about different dividend policy issues. Panel B contains five statements showing respondents opinion about dividend processes and settings of their companies. The responses of investors for all five statements (S1, S2, S3, S4, S5) significantly differ from 3 (no opinion) 
at 1 per cent level of significance. Approximately 83 per cent of shareholders either strongly agree or agree that their companies should alter dividend policy based on continual transformation in future earnings (S5). Almost 81 per cent of the investors believe that their companies must maintain a target payout ratio that can constantly be adjusted according to the policy requirement (S3). 74 per cent of investors think that their companies should sustain an uninterrupted record of dividend payments (S1). Close to 72 per cent of the stockholder's regard changing regular dividends negatively (S2). Almost 65 per cent of investors give higher value to the stability of dividend amount on the ratio (S4). Overall, these results express a strong preference for investors for cash dividends.

Table 4(b): Dividend Policy Issues

\begin{tabular}{|c|c|c|c|c|c|c|c|c|c|}
\hline \multirow{2}{*}{ S\# } & \multirow{2}{*}{ Statements } & SD & D & No & $\mathbf{A}$ & SA & \multirow{2}{*}{ Mean } & \multirow{2}{*}{ Std. } & \multirow{2}{*}{ t-value } \\
\hline & & 1 & 2 & 3 & 4 & 5 & & & \\
\hline \multicolumn{10}{|c|}{ Panel B. Dividend Process } \\
\hline S1 & $\begin{array}{l}\text { A firm should strive to maintain an } \\
\text { uninterrupted record of dividend } \\
\text { payments }\end{array}$ & 6.87 & 14.5 & 4.6 & 57 & 16.8 & 3.626 & 0.132 & $36.652^{* *}$ \\
\hline S4 & $\begin{array}{l}\text { The market places greater value on } \\
\text { stable dividends than stable payout } \\
\text { ratios }\end{array}$ & 9.16 & 16.8 & 9.2 & 47 & 17.6 & 3.473 & 0.224 & $32.487^{* *}$ \\
\hline S3 & $\begin{array}{l}\text { A firm should have a target } \\
\text { dividend payout ratio and } \\
\text { periodically adjust the payout } \\
\text { toward the target }\end{array}$ & 6.11 & 10.7 & 2.3 & 62 & 19.1 & 3.771 & 0.071 & $40.298^{* *}$ \\
\hline S2 & $\begin{array}{l}\text { A firm should avoid changing its } \\
\text { regular dividend if it had to reverse } \\
\text { that change in a year or so because } \\
\text { this may create an unfavorable } \\
\text { impression among investors about } \\
\text { the firm }\end{array}$ & 6.87 & 14.5 & 6.9 & 53 & 18.3 & 3.618 & 0.147 & $36.118^{* *}$ \\
\hline S5 & $\begin{array}{l}\text { Dividends changes generally follow } \\
\text { a shift in long-term sustainable } \\
\text { earnings }\end{array}$ & 6.11 & 8.4 & 2.3 & 71 & 12.2 & 3.748 & 0.987 & $43.456^{* *}$ \\
\hline \multicolumn{10}{|c|}{ Panel C. Stock Dividends } \\
\hline S6 & $\begin{array}{l}\text { I prefer to receive stock dividends if } \\
\text { company is not paying cash } \\
\text { dividends }\end{array}$ & 3.1 & 22.1 & 15.3 & 48.9 & 10.7 & 3.420 & 0.045 & $37.464^{* *}$ \\
\hline S10 & $\begin{array}{l}\text { I prefer stock dividends due to } \\
\text { transaction cost }\end{array}$ & 8.4 & 15.3 & 11.5 & 46.6 & 18.3 & 3.511 & 0.199 & $33.534^{* *}$ \\
\hline S7 & $\begin{array}{l}\text { Stock dividends are more like stock } \\
\text { split }\end{array}$ & 6.9 & 32.8 & 24.4 & 22.9 & 13.0 & 3.023 & 0.167 & $29.657^{* *}$ \\
\hline \multicolumn{10}{|c|}{ Panel D. Share Buy-backs Decisions } \\
\hline S8 & $\begin{array}{l}\text { I consider the act of company } \\
\text { extremely positive if it stops paying } \\
\text { dividends and instead uses the } \\
\text { money to buy back its stocks on the } \\
\text { market. }\end{array}$ & 26.0 & 33.6 & 3.8 & 27.5 & 9.2 & 2.6031 & 1.3682 & 21.775 \\
\hline
\end{tabular}


Shahid Mahmood

\begin{tabular}{|c|c|c|c|c|c|c|c|c|c|}
\hline \multirow{2}{*}{ S\# } & \multirow{2}{*}{ Statements } & SD & D & No & $\mathbf{A}$ & SA & \multirow{2}{*}{ Mean } & \multirow{2}{*}{ Std. } & \multirow{2}{*}{$\mathrm{t}$-value } \\
\hline & & 1 & 2 & 3 & 4 & 5 & & & \\
\hline$\overline{\text { S9 }}$ & $\begin{array}{l}\text { Stock repurchase is good because it } \\
\text { is a signal that the stock is } \\
\text { undervalued }\end{array}$ & 13.7 & 26.0 & 23.7 & 22.9 & 13.7 & 2.9695 & 1.2645 & 26.877 \\
\hline \multicolumn{10}{|c|}{ Panel E. Firm Value } \\
\hline S11 & $\begin{array}{l}\text { An optimal dividend policy strikes } \\
\text { a balance between current } \\
\text { dividends and future growth that } \\
\text { maximizes firms' value }\end{array}$ & 0 & 0 & 5.3 & 60.3 & 34.4 & 4.237 & 0.711 & $68.228^{* *}$ \\
\hline S13 & $\begin{array}{l}\text { A firm's dividend policy affects its } \\
\text { cost of capital }\end{array}$ & 5.3 & 14.5 & 6.1 & 51.9 & 22.1 & 3.710 & 0.127 & $37.693^{* *}$ \\
\hline S14 & $\begin{array}{l}\text { A firm's investment, financing, and } \\
\text { dividend decisions are interrelated }\end{array}$ & 2.3 & 6.1 & 0.8 & 76.3 & 14.5 & 3.947 & 0.778 & $58.082^{* *}$ \\
\hline S12 & $\begin{array}{l}\text { Any change in dividend policy is } \\
\text { likely to affect firm value }\end{array}$ & 8.4 & 9.2 & 7.6 & 50.4 & 24.4 & 2.267 & 0.176 & $22.074^{* *}$ \\
\hline \multicolumn{10}{|c|}{$\begin{array}{l}\text { Panel F. Accounting Manipulations } \\
\text { Effect }\end{array}$} \\
\hline S15 & $\begin{array}{l}\text { Dividend-paying stocks offer more } \\
\text { certainty about the companies' } \\
\text { future earnings prospects }\end{array}$ & 3.1 & 6.1 & 2.3 & 58.0 & 30.5 & 4.069 & 0.921 & $50.538^{* *}$ \\
\hline S16 & $\begin{array}{l}\text { Dividend-paying companies } \\
\text { generate real earnings and are less } \\
\text { likely to "cook the books" }\end{array}$ & 0 & 0 & 0 & 69.5 & 30.5 & 4.305 & 0.462 & $106.586^{* *}$ \\
\hline
\end{tabular}

${ }^{*} \mathrm{p}<0.05,{ }^{* *} \mathrm{p}<0.01$

Panel C shows the significant results for stock dividends. Approximately 60 per cent of shareholders expressed their priority for stock dividends, indicating they agree or strongly agree if their companies are unable to pay cash dividends (S6), whereas 65 per cent of stockholders prefer it due to transaction cost (S10). These results further illustrate that investors were still not aware of the differentiation of stock dividends and stock split because 60 per cent of investors believe either they do not know or consider stock dividends and stock splits to be similar (S7). These findings are consistent with the results of Maditinos et al. (2007). Panel D includes two statements about share buy-back decisions, which show insignificant results. Pakistani investors strongly discourage share buy-back decisions, and these results highlight their preferences for cash dividends.

Panel E includes four statements (S11, S13, S14, S12) stating investors' viewpoint about the relationship of dividend policy and firm value. Results have indicated that all the statements show respondents' agreement on this relationship. Almost 95 per cent of the stockholders agree that optimal dividend policy creates a harmony between current dividends and a future growth rate that, in turn, boosts the firms' value (S11). Close to 91 per cent of respondents have a strong opinion that firms' financing, investment, and dividend decisions are interlinked (S14). Almost 75 per cent of respondents believe that any change in dividend 
policy is likely to affect the firm value (S12). Approximately 74 per cent of respondents think dividend policy is affected by the cost of capital (S13).

The significant results are shown in Panel F for the statements (S15, S16) that highlight essential reasons for investors expecting dividends. Investors demand dividends because they consider dividend-paying companies as honest and less subject to be involved in fraudulent activities (Dong et al., 2005). Dividend-paying stocks provide positive conviction and inevitability regarding the firms' future perspective (Khan et al., 2011). Therefore, companies pay dividends for image-building purposes and keep the stock prices stable.

\subsection{Explanations for Paying Cash Dividends}

The final research question explains the investor perception for a cash dividend. Table 5 illustrates the extent of support that respondents ascribe to seven possible justifications for preferring cash dividends. Panel A of Table 5 reports mixed support to the bird-in-hand theory. Five statements are included to comprehend the responses of investors and only two (S21, S12) of them show statistically supportive results, which indicate Pakistani investors prefer dividends because they consider dividendpaying companies to be less risky and also alleviates a vague or erratic increase in future stock price by the organizations.

Panel B represents the responses of investors in three statements for signaling theory. These significant findings specify that shareholders regard dividends as essential due to its positive signaling mechanism about the future earnings and growth perspective of the organization. These results are pertinent to the findings of $\mathrm{H}$. K. Baker and Jabbouri (2016), Clark-Murphy and Soutar (2004) and Travlos et al. (2001). These scholars have also expressed their belief in the strong signaling role of dividend decisions to convey positive or negative signals about the progress of the organization to both current or prospective shareholders and investors. The increasing or consistent dividends communicate optimistic signals, whereas declining dividends publicize adverse vibes in the stock market. 
Table 5: Investors' Perceptions of Cash dividends

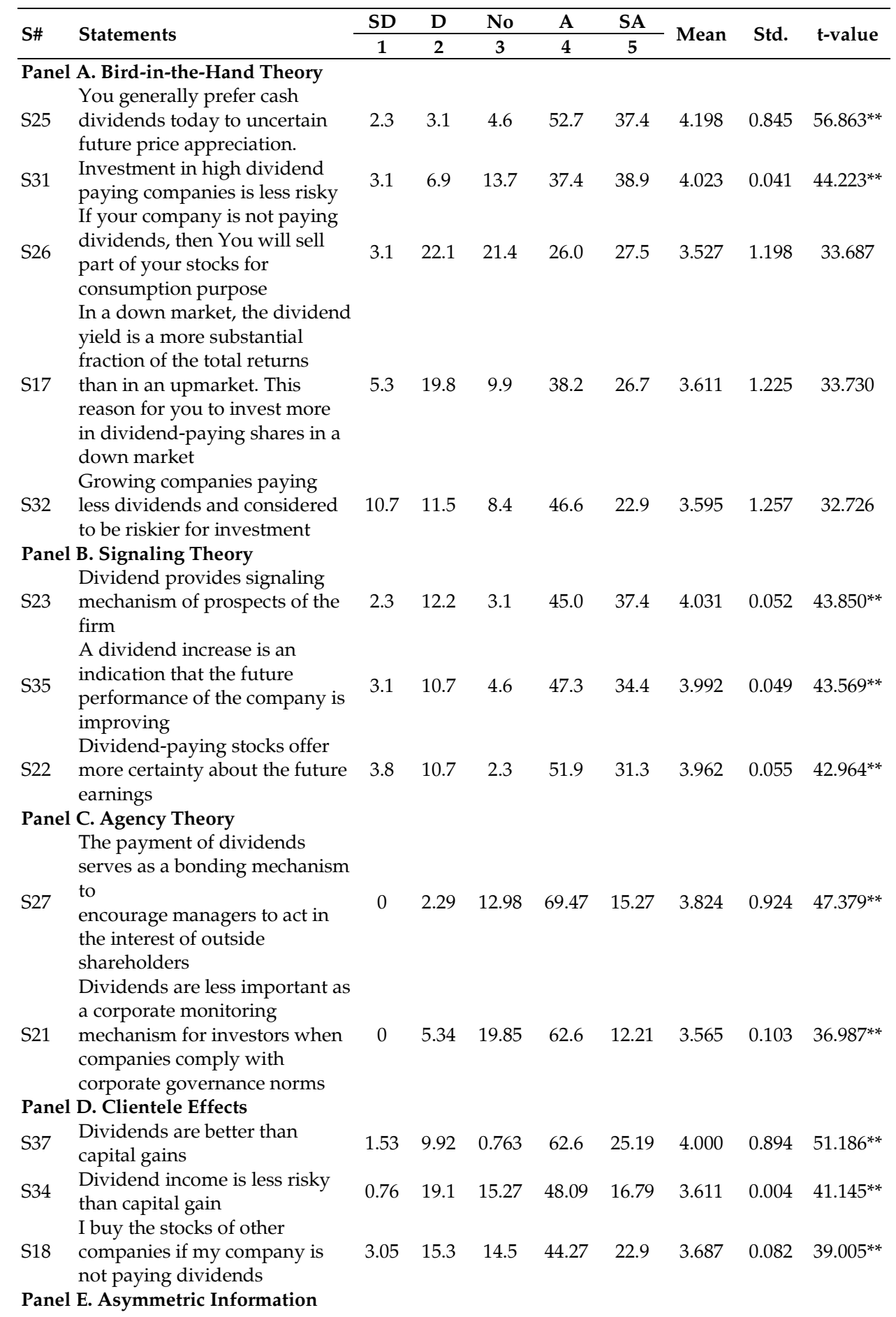




\begin{tabular}{|c|c|c|c|c|c|c|c|c|c|}
\hline \multirow{2}{*}{ S\# } & \multirow{2}{*}{ Statements } & SD & D & No & $\mathbf{A}$ & SA & \multirow{2}{*}{ Mean } & \multirow{2}{*}{ Std. } & \multirow{2}{*}{ t-value } \\
\hline & & 1 & 2 & 3 & 4 & 5 & & & \\
\hline S20 & $\begin{array}{l}\text { Managers and directors have } \\
\text { greater access to the company' } \\
\text { inside information that } \\
\text { investors }\end{array}$ & 0 & 3.82 & 11.45 & 61.07 & 23.66 & 3.893 & 0.017 & $43.807^{* *}$ \\
\hline S38 & $\begin{array}{l}\text { Information asymmetry affect } \\
\text { the dividend policy of my } \\
\text { company }\end{array}$ & 0 & 5.34 & 10.69 & 51.91 & 32.06 & 3.947 & 0.112 & $40.637^{* *}$ \\
\hline \multicolumn{10}{|c|}{ Panel F. Tax Effects } \\
\hline S 36 & $\begin{array}{l}\text { Dividends are taxed at higher } \\
\text { rate than capital gain }\end{array}$ & 3.82 & 26.7 & 3.817 & 45.04 & 20.61 & 3.519 & 0.198 & $33.610^{* *}$ \\
\hline S19 & $\begin{array}{l}\text { You prefer to receive dividends } \\
\text { despite tax disadvantage }\end{array}$ & 3.82 & 19.8 & 2.29 & 51.91 & 22.14 & 3.687 & 0.137 & $37.103^{* *}$ \\
\hline S28 & $\begin{array}{l}\text { you submit an income tax } \\
\text { return to claim reimbursement } \\
\text { of the dividend surtax }\end{array}$ & 0 & 4.58 & 7.634 & 45.04 & 42.75 & 4.137 & 0.065 & $44.453^{* *}$ \\
\hline Pane & $\begin{array}{l}\text { G. Residual Theory } \\
\text { I invest in dividend paying } \\
\text { stocks during the economic }\end{array}$ & & & & & & & & \\
\hline S 33 & $\begin{array}{l}\text { downturns when fewer good } \\
\text { investment projects are } \\
\text { available. }\end{array}$ & 34.4 & 30.5 & 7.634 & 16.79 & 10.69 & 2.389 & 1.384 & 19.754 \\
\hline S24 & $\begin{array}{l}\text { I wish to receive dividends } \\
\text { because I believe the company } \\
\text { will otherwise invest the } \\
\text { money unprofitably }\end{array}$ & 9.16 & 19.1 & 6.107 & 48.85 & 16.79 & 3.450 & 0.235 & $31.965^{* *}$ \\
\hline S29 & $\begin{array}{l}\text { I want to receive the dividends } \\
\text { even if company has more } \\
\text { profitable opportunities inside }\end{array}$ & 15.3 & 44.3 & 12.21 & 17.56 & 10.69 & 2.641 & 1.241 & 24.364 \\
\hline \multicolumn{10}{|c|}{ Panel H. Rational Expectation } \\
\hline S30 & $\begin{array}{l}\text { I like to hold the stocks of the } \\
\text { company even if it does not } \\
\text { announce its dividend policy } \\
\text { per your expectation }\end{array}$ & 0 & 4.58 & 21.37 & 50.38 & 23.66 & 3.672 & 0.187 & $35.432^{* *}$ \\
\hline
\end{tabular}

The significant responses of investors about agency theory presented in Panel $C$ highlighted their recognition about the agency issues. Two statements (S27, S21) were included, and their results presented the severity of the problem. 84 per cent of investors believe dividend payments can remove agency conflicts between shareholders and managers as shareholders take it positively, while 75 per cent of the shareholders take dividend policy as less important as a corporate monitoring mechanism, especially when companies comply with corporate governance norms. Panel D provides the significant results for clientele effect. 88 per cent of stockholders have a strong preference for dividend income (S37), 65 per cent consider it more stable and secure (S34) than capital gains. 67 per cent of respondents stated that they would sell the stocks of their companies if their companies stop paying dividends and would start purchasing dividend paying stocks (S18). 


\section{Shahid Mahmood}

Results of Panel E support the existence of asymmetric information effect. We included two statements (S20, S38) which are statistically different from 3 (no opinion) at 1 per cent level. About 85 per cent of shareholders admitted that company management can conveniently utilize inside information regarding policy decisions (S20), and almost 84 per cent believe that this information asymmetry can influence their dividend policy decisions and stock market prices (S38). Studies conducted by Azofra, Castrillo and Maria (2003) and Dorn and Huberman (2010) also supports the results of the present study. Panel $\mathrm{F}$ provides consistent significant results for tax effect at 1 per cent level for all three statements (S19, S28, S36). These results are consistent with the studies conducted by Korkeamaki et al. (2010) and Brennan and Thakor (1990), who have explained the substantial role of corporate taxes in modifying the shareholders' preferences regarding dividend decisions.

Findings of Panel $G$ for Table 5 show results that fail to reach significance for a residual theory for all three statements (S24, S29, S33). These findings have indicated that Pakistani shareholders consider it to be extremely important that dividends be paid consistently and regularly. They do not regard it as residual income. These results further highlight the importance of dividends from the investors' point of view. Panel $\mathrm{H}$ provides the significant support for the rational expectation theory. Respondents were asked to express their beliefs about their firms' dividend policy. 77 per cent of shareholder stated that they will sell the shares of their companies if management does not announce its dividend policy according to their expectation (S30).

Finally, results have shown that the signaling theory, asymmetric information effect, agency cost, clientele effect and tax effect and rational expectation model are favored while Pakistani investors do not support bird-in-the-hand and residual theory. Overall findings of the present study have explained that shareholders regard dividend policies as substantially important in designing their portfolios. Dividend payments act as a signaling mechanism and provide viable signals about the prosperity of the organization, which is why it significantly affects the investors' perception as well.

\section{Discussion and Conclusion}

This study was conducted to express the opinion of investors about dividend policy issues, patterns, and important factors affecting dividend decisions. It also provided the theoretical explanation for dividend 
preferences within the context of Pakistani corporate sector. For this purpose, primary research was conducted using the questionnaire technique from investors to specify the effect of corporate dividend policy on investors' perception and belief. The present study has five main findings: first, results show that stability in the rate of dividend, compatibility with the inflation rate, continuity of dividend payment and prior patterns of the dividend are the top-ranking factors for investors that affect their expectations regarding dividend policy.

Second, investors described the dividend policy of their companies as the fixed dividend (in percentage) of EPS policy, constant dividend per share plus special dividend policy or dividend percentage of net income plus growth factor policy in the best possible ways.

Third, with regard to dividend process and settings, investors mainly believed their companies must change dividend policies based on a sustainable shift in future earnings. Investors also demanded target payout ratios and that the company should be consistently adjusting its current payout ratio towards the target ratio. Investors also required maintaining an uninterrupted record of dividend payment. Overall, investors agreed on keeping regular and stable payout ratios.

Fourth, investors preferred stock dividends if their companies do not pay cash dividends, but they discouraged share buy-back decisions. They believed dividend decisions have a strong influence on firm value. Lastly, the theoretical explanation for preferring cash dividend indicates that dividend signaling theory, asymmetric information effect, agency cost, clientele effect and rational expectation model are favored by Pakistani stockholders and show a positive relationship between dividend policy and investors' perception. Pakistani investors do not support bird-in-thehand and residual theory.

\subsection{Limitations and Future Recommendations}

This study faces certain limitations that are necessary to be addressed by future researchers. First, the sample size of the study is limited, and focused on listed companies only; future researchers should consider larger sample sizes to provide more comprehensive views about dividend decisions. Future researchers should perhaps use cluster sampling technique and include investors from all the sectors of the economy. Secondly, the current study is based on a close-ended survey instrument that does not provide freedom to the respondents to express 
their opinion. Future researchers should include open-ended questions as well, so that investors can express their views more deliberately. Thirdly, this study ignores the effect of the amount of investment. Investors perception based on investment may be diversified. Investors may perceive dividend policy differently from their investment point of view. So, future researchers may also value the amount of investment as well. Finally, a comparative study of managers, executives, and shareholders of similar companies is needed in the future to know their differences of opinion and priorities about dividend decisions. 


\section{References}

Akbar, M., \& Baig, H. H. (2010). Reaction of stock prices to dividend announcements and market efficiency in Pakistan. The Lahore Journal of Economics, 15(1), 103-125.

Anand, M. (2004). Factors influencing dividend policy decisions of corporate India. ICFAI Journal of Applied Finance, 10(2), 5-16.

Asquith, P., \& Mullins, D. W. (1986). Signalling with dividends, stock repurchases, and equity issues. Financial Management, 15(3), 27-44.

Azofra, V., Castrillo, L., \& Maria, d. M. D. (2003). Ownership concentration, debt financing and the investment opportunity set as determinants of accounting discretion: Empirical evidence from Spain. Spanish Journal of Finance and Accounting/Revista Española de Financiación y Contabilidad, 32(115), 215-255.

Babbie, E. R. (2015). The practice of social research (13th ed.): International Thomson Publishing Services.

Baker, H. K., \& Jabbouri, I. (2016). How Moroccan managers view dividend policy. Managerial Finance, 42(3), 270-288.

Baker, H. K., \& Kapoor, S. (2015). Dividend policy in India: New survey evidence. Managerial Finance, 41(2), 182-204.

Baker, H. K., Powell, G. E., \& Veit, E. T. (2002). Revisiting managerial perspectives on dividend policy. Journal of Economics and Finance, 26(3), 267-283.

Baker, M., \& Wurgler, J. (2002). Market timing and capital structure. The Journal of Finance, 57(1), 1-32.

Beal, D. J., \& Delpachitra, S. B. (2003). Financial literacy among Australian university students. Economic Papers: A Journal of Applied Economics and Policy, 22(1), 65-78.

Brav, A., Graham, J. R., Harvey, C. R., \& Michaely, R. (2005). Payout policy in the 21st century. Journal of Financial Economics, 77(3), 483-527.

Brennan, M. J., \& Thakor, A. V. (1990). Shareholder preferences and dividend policy. The Journal of Finance, 45(4), 993-1018. 
Butler, A. W., Grullon, G., \& Weston, J. P. (2005). Can managers forecast aggregate market returns? The Journal of Finance, 60(2), 963-986.

Chen, H., \& Volpe, R. P. (1998). An analysis of personal financial literacy among college students. Financial Services Review, 7(2), 107-128.

Clark-Murphy, M., \& Soutar, G. N. (2004). What individual investors value: Some Australian evidence. Journal of Economic Psychology, 25(4), 539-555.

Dong, M., Robinson, C., \& Veld, C. (2005). Why individual investors want dividends. Journal of Corporate Finance, 12(1), 121-158.

Dorn, D., \& Huberman, G. (2010). Preferred risk habitat of individual investors. Journal of Financial Economics, 97(1), 155-173.

Easterbrook, F. H. (1984). Two agency-cost explanations of dividends. The American Economic Review, 74(4), 650-659.

Ehrhardt, M., \& Brigham, E. (2016). Corporate finance: A focused approach (5th ed.): Cengage Learning.

Gordon, M. J. (1959). Dividends, earnings, and stock prices. The Review of Economics and Statistics, 42(2), 99-105.

Jensen, M. C., \& Meckling, W. H. (1976). Theory of the firm: Managerial behavior, agency costs and ownership structure. Journal of Financial Economics, 3(4), 305-360.

Jong, A. D., Ronald, V. D., \& Chris, V. (2003). The dividend and share repurchase policies of Canadian firms: empirical evidence based on an alternative research design. International Review of Financial Analysis, 12(4), 349-377.

Khan, K. I. (2012 . Management, 2(5), 141-148.

Khan, K. I., Aamir, M., Qayyum, A., Nasir, A., \& Khan, M. I. (2011). Can dividend decisions affect the stock prices: A case of dividend paying companies of KSE. International Research Journal of Finance and Economics, 76(68), 69-74. 
Korkeamaki, T., Liljeblom, E., \& Pasternack, D. (2010). Tax reform and payout policy: Do shareholder clienteles or payout policy adjust? Journal of Corporate Finance, 16(4), 572-587.

Lee, B., Rosenthal, L., Veld, C., \& Veld-Merkoulova, Y. (2015). Stock market expectations and risk aversion of individual investors. International Review of Financial Analysis, 40, 122-131.

Lintner, J. (1956). Distribution of incomes of corporations among dividends, retained earnings, and taxes. The American Economic Review, 46(2), 97-113.

Maditinos, D. I., Sevic, Z., Theriou, N. G., \& Tsinani, A. V. (2007). Individual investors' perceptions towards dividends: The case of Greece. International Journal of Monetary Economics and Finance, 1(1), 18-31.

Mathur, I., Singh, M., Nejadmalayeri, A., \& Jiraporn, P. (2013). How do bond investors perceive dividend payouts? Research in International Business and Finance, 27(1), 92-105.

Miller, M. H., \& Rock, K. (1985). Dividend policy under asymmetric information. The Journal of Finance, 40(4), 1031-1051.

Naser, K., Nuseibeh, R., \& Rashed, W. (2013). Managers' perception of dividend policy: Evidence from companies listed on Abu Dhabi Securities Exchange. Issues in Business Management and Economics, 1(1), 1-12.

Ross, S. A., Westerfield, R. W., \& Jaffe, J. (2013). Corporate Finance (10th ed.). New York: The McGraw-Hill Companies, Inc.

Travlos, N. G., Trigeorgis, L., \& Vafeas, N. (2001). Shareholder wealth effects of dividend policy changes in an emerging stock market: The case of Cyprus. Multinational Finance Journal, 5(2), 87-112.

Yao, L. J., Baker, H. K., \& Powell, G. E. (2012). Dividend policy in Indonesia: Survey evidence from executives. Journal of Asia Business Studies, 6(1), 79-92. 